\title{
Production of calcium-fortified milk powders using soluble calcium salts
}

\author{
Roderick P.W. WILLIAMS*, Lynette D’ATH, Mary Ann AUGUSTIN \\ Food Science Australia, Werribee Laboratory, Private bag 16, Werribee, Victoria 3030, Australia
}

Published online 24 June 2005

\begin{abstract}
The choice of appropriate calcium salts for fortification of milk or milk powders is a challenge for the dairy industry. Depending on the form of salt used, the addition of calcium to dairy products has the potential to influence the colour, texture, stability, flavour, and processing characteristics of the final product. A novel strategy was developed for the calcium fortification of liquid milk and calcium-fortified milk powders, based on results obtained in liquid milk systems. The process involves adding a combination of orthophosphates with a soluble calcium salt (calcium chloride) to milk, subjecting the milk to low-heat $\left(72{ }^{\circ} \mathrm{C} / 30 \mathrm{~s}\right)$ or high-heat $\left(90{ }^{\circ} \mathrm{C} / 10 \mathrm{~min}\right)$ treatment, concentrating the milk to approximately $450 \mathrm{~g}$ total solids $\cdot \mathrm{kg}^{-1}$ and spray drying the concentrate to produce powders with approximately $50 \mathrm{~g} \cdot \mathrm{kg}^{-1}$ moisture. Calcium-fortified skim and milk powders with up to an extra $8 \mathrm{~g}$ of calcium per $\mathrm{kg}$ of powder were prepared. These powders were easily reconstituted in water to give skim milk solutions ( $100 \mathrm{~g}$ total solids $\left.\cdot \mathrm{kg}^{-1}\right)$ with a total calcium content of between 2000 and $2300 \mathrm{mg} \mathrm{Ca} \cdot \mathrm{L}^{-1}$. The total concentration of calcium in the fortified powder depends on the level of calcium in the base milk from which it is produced. Recovery rates of at least $97 \%$ were obtained in the final powders. This strategy can be used for the production of both high-heat and low-heat milk powders with increased calcium levels.
\end{abstract}

milk powder / fortification / calcium / heat stability

Résumé - Production de laits en poudre enrichis en calcium par l'emploi de sels de calcium solubles. Le choix de sels de calcium pour l'enrichissement du lait ou de laits en poudre représente un défi pour l'industrie laitière. Selon la forme du sel qui est utilisé, l'addition de calcium aux produits laitiers a le potentiel d'influencer la couleur, la texture, la stabilité, l'arôme et les caractéristiques de fabrication du produit final. Une nouvelle stratégie a été développée pour l'enrichissement en calcium du lait liquide et des laits en poudre, basée sur les résultats obtenus dans les systèmes de lait liquide. La technique implique l'addition au lait d'une combinaison d'orthophosphates et d'un sel soluble de calcium (chlorure de calcium) puis un traitement thermique à basse $\left(30 \mathrm{~s}\right.$ à $\left.72{ }^{\circ} \mathrm{C}\right)$ ou haute $\left(10\right.$ min à $\left.90^{\circ} \mathrm{C}\right)$ température ; le lait est ensuite concentré jusqu'à un extrait sec de $450 \mathrm{~g} \cdot \mathrm{kg}^{-1}$ puis déshydraté par atomisation pour obtenir des poudres à $5 \%$ d'humidité. On a pu ainsi préparé des laits en poudre écrémés enrichis en calcium de $8 \mathrm{~g}$ par $\mathrm{kg}$ de poudre. Ces laits en poudre étaient facilement reconstitués sous forme liquide pour donner des laits reconstitués écrémés à $100 \mathrm{~g}$ d'extrait sec par kg avec des teneurs en calcium comprises entre 2000 et $2300 \mathrm{mg}$ par litre. La concentration totale de calcium dans le lait en poudre enrichi dépend du niveau de calcium dans le lait de base à partir duquel il est produit. Des taux de récupération d'au moins $97 \%$ ont été obtenus dans les poudres finales. Cette stratégie peut être utilisée pour la production de laits en poudre à la fois à haute et basse température avec des taux accrus en calcium.

\section{poudre de lait / enrichissement / calcium / stabilité thermique}

* Corresponding author: roderick.williams@csiro.au 


\section{INTRODUCTION}

Calcium fortification is a growing trend in the food industry. Milk and dairy products have a healthy image and are ideal vehicles for delivery of additional calcium and other minerals $[8,19]$. Calcium has a vital role in bone health and concern about the risk of osteoporosis has heightened the interest in calcium-fortified foods. An adequate calcium intake has been associated with reduced risk of hypertension, colon cancer and kidney stones, although more work is needed to obtain more definitive links between calcium and disease [26]. Calcium has an essential role in muscle contraction, blood clotting, and hormone regulation and enzyme activation. As more consumers are made aware of the health benefits of calcium, an increasing number of new calcium-fortified products are being marketed [6, 17, 18].

Strategies used for calcium fortification range from the addition of soluble calcium in the form of mineral and/or organic salts, the use of insoluble calcium salts as fine particles in suspension often with additional gums or thickeners, or utilize calcium associated with protein. Although the addition of insoluble calcium salts has been used, there are problems encountered with the use of this strategy. There is risk of sedimentation of the calcium salt in the liquid milk. When insoluble calcium sources are dry blended with milk powder, there is risk of precipitation on reconstitution of milk powder containing soluble calcium salts in hot water [8]. This will depend on the source of soluble calcium used and the temperature of the water used for reconstitution.

When using soluble calcium salts for fortification of milk, there is a need to consider the complex equilibrium between the proteins and minerals in milk [4]. In a typical milk with a total calcium concentration of $\sim 30 \mathrm{mmol} \cdot \mathrm{L}^{-1}$, the concentration within the colloidal phase is $20 \mathrm{mmol} \cdot \mathrm{L}^{-1}$ and the serum phase contains a total of $10 \mathrm{mmol} \cdot \mathrm{L}^{-1}$ calcium at $\mathrm{pH}$ 6.70. Of the serum calcium, $2 \mathrm{mmol} \cdot \mathrm{L}^{-1}$ is free calcium [11]. Holt has proposed a model structure for the colloidal phase of milk based on the formation of nano-clusters with a core / shell structure
[13]. Various workers have demonstrated that calcium and other minerals can move from phase to phase when conditions such as the $\mathrm{pH}$, ionic strength or temperature [11] of milk is changed, or when calcium chelating salts are added [25]. Within the serum phase there is a further partition between free ionic forms of the salts and salts complexed with other components. Re-distribution of these salts from one phase to the other can also give rise to a re-distribution of the casein proteins between the phases of milk [11].

The interactions of proteins and calcium have a marked influence on the heat stability of milk, an important functional property of milk. Generally the addition of calcium salts to milk causes an increase in serum calcium ions, an increase in calcium in the colloidal phase, a decrease in $\mathrm{pH}$, and a decrease in heat stability. Reduction of the calcium ion concentration by the addition of phosphate or citrate generally causes an increase in heat stability [1,23].

Most researchers have used calcium sequestering agents for stabilization of calcium-fortified milks but very few of the strategies claim to be able to create a calcium-fortified milk that can withstand high heat treatments. Some notable exceptions are milk fortified with a soluble calcium source that is made stable to the heat treatment used in yoghurt manufacture through the addition of citrates and $\mathrm{pH}$ adjustment [9]. Citrates have also been used [7, 10, 14] for the production of calcium-fortified UHT milk but in two of these cases $[10,14]$ the calcium and milk are sterilised separately and then mixed aseptically when cool and in the third [7] carrageenans are also needed for stability. The use of calcium phosphate nanoclusters derived from milk, has been described for food and pharmaceutical applications [12].

The aim of this work was to develop a strategy involving the addition of a soluble calcium salt in combination with orthophosphate and $\mathrm{pH}$ manipulation for the manufacture of calcium-fortified milk powders. The target was milk powders with an additional $8 \mathrm{~g}$ of calcium per $\mathrm{kg}$ of powder. Reconstitution of these powders will give skim milks (100 $\mathrm{g}$ total solids $\cdot \mathrm{kg}^{-1}$ ) and 
full-cream milks ( $125 \mathrm{~g}$ total solids $\cdot \mathrm{kg}^{-1}$ ) with a calcium level in excess of $2000 \mathrm{mg} \cdot \mathrm{L}^{-1}$.

\section{MATERIALS AND METHODS}

\subsection{Materials}

Full-cream milk was obtained from Tatura Milk Industries (Tatura Vic., Australia) and processed into low-heat $\left(72{ }^{\circ} \mathrm{C} / 30 \mathrm{~s}\right)$ or high-heat $\left(85^{\circ} \mathrm{C} / 30 \mathrm{~min}\right)$ skim milk powder at the Food Science Australia processing facility, as previously described [2].

All reagents were analytical grade unless otherwise specified. Calcium chloride dihydrate $\left(\mathrm{CaCl}_{2} \cdot 2 \mathrm{H}_{2} \mathrm{O}\right)$, sodium dihydrogen phosphate dihydrate $\left(\mathrm{NaH}_{2} \mathrm{PO}_{4} \cdot 2 \mathrm{H}_{2} \mathrm{O}\right.$, GPR grade), potassium hydroxide $(\mathrm{KOH}$, GPR grade), tri-potassium orthophosphate $\left(\mathrm{K}_{3} \mathrm{PO}_{4} \cdot \mathrm{H}_{2} \mathrm{O}\right.$, GPR grade), di-potassium hydrogen orthophosphate $\left(\mathrm{K}_{2} \mathrm{HPO}_{4}\right)$, potasium dihydrogen orthophosphate, $\left(\mathrm{KH}_{2} \mathrm{PO}_{4}\right)$, hydrochloric acid $(\mathrm{HCl})$, trichloroacetic acid and trisodium citrate $\left(\mathrm{Na}_{3} \mathrm{C}_{6} \mathrm{H}_{5} \mathrm{O}_{7}\right)$ were obtained from Merck (Kilsyth, Australia). Sodium pyrophosphate $\left(\mathrm{Na}_{4} \mathrm{P}_{2} \mathrm{O}_{7}\right)$, sodium tripolyphosphate $\left(\mathrm{Na}_{5} \mathrm{P}_{3} \mathrm{O}_{10}\right.$, Technical grade $)$ and strontium chloride were obtained from Ajax Chemicals (Sydney, Australia). Polyphosphate $\left(\mathrm{Na}_{n+2} \mathrm{P}_{n} \mathrm{O}_{3 n+1}, n\right.$ predominantly = 10 12) was obtained from Albright and Wilson (Yarraville, Australia) as Calgon ${ }^{\circledR} \mathrm{T}$. Calgon is the registered trade name of amorphous sodium polyphosphates manufactured by Albright and Wilson.

For capillary electrophoresis experiments, urea, dithiothreitol, and purified milk proteins: $\alpha$-casein (C6780), $\beta$-casein (C6905), $\kappa$-casein (C0406), $\beta$-lactoglobulin (L2506) $\alpha$-lactalbumin (L5385) and Gly-Tyr dipeptide were obtained from Sigma-Aldrich (Castle Hill, Australia). Methyl-hydroxyethyl-cellulose (MHEC) was obtained from Serva (Heidelberg, Germany).

\subsection{Methods}

\subsubsection{Preparation of reconstituted milk mixtures}

For initial experiments, fortified milks were produced by combining reconstituted milk powder solutions with solutions of the required salts. Milks were reconstituted at approximately $130 \mathrm{~g}$ total solids $\cdot \mathrm{kg}^{-1}$ by dispersing the required mass of unfortified low-heat milk powder in distilled water with continuous stirring at room temperature. Once dispersed, the milks were stirred for at least one hour to ensure full hydration and equilibration. The mineral contents of the milks were adjusted by the addition of the appropriate volumes of salt solutions. When used, solutions of orthophosphates or other calcium-sequestering agents were added before calcium solutions. In most cases, the concentration of the stock salt solutions was $200 \mathrm{mmol} \cdot \mathrm{L}^{-1}$. Where required, water was added so that the final milk solids concentration of the solutions was $100 \mathrm{~g} \cdot \mathrm{kg}^{-1}$. Once adjusted, the solutions were left for a further hour to equilibrate and then used in experiments.

\subsubsection{Nitrogen fractions}

Total nitrogen (TN) content of milk powders and solutions was determined by a semi-micro Kjeldahl procedure [21]. Determination of nitrogen soluble at $\mathrm{pH} 4.6$ was based on the Standards Association of Australia procedure [20]. Non-protein nitrogen (NPN) was measured as nitrogen soluble in $120 \mathrm{~g}$ trichloroacetic acid $\cdot \mathrm{L}^{-1}$. Crude protein was calculated as $\mathrm{TN} \times 6.38$. True protein was calculated as (TN-NPN) $\times 6.38$. Whey protein was calculated as $(\mathrm{N}$ soluble at $\mathrm{pH} 4.6-\mathrm{NPN}) \times 6.38$. In control low-heat milk powder, casein protein was calculated as true protein - whey protein.

\subsubsection{Analysis of calcium and $\mathrm{pH}$}

The total calcium content of the milks and supernatant fractions was determined by atomic absorption spectroscopy by a modification of the method of Schmidt [22] using a Varian SpectrAA-10. The samples were prepared for analysis by precipitation using $120 \mathrm{~g} \cdot \mathrm{kg}^{-1}$ trichloroacetic acid (final, $\mathrm{w} / \mathrm{w})$, filtration, and dilution. Strontium chloride was used as a releasing agent in the diluents to minimise interference effects. Free calcium activity of samples was determined using a $\mathrm{Ca}^{2+}$-specific electrode 
(Radiometer F2112) following the method of Augustin and Clarke [2]. The $\mathrm{pH}$ of samples was determined using a PHM 93 reference $\mathrm{pH}$ meter fitted with a PHC2401 electrode (Radiometer Pacific, Blackburn, Australia).

\subsubsection{Measurement of viscosity}

The viscosity of heated milks was determined at room temperature using a Brookfield LVDV-II viscometer fitted with a UL adaptor (Brookfield Engineering Laboratories Inc., MA, USA). Measurements were recorded at $30 \mathrm{rpm}$ (equivalent to $36.1 \mathrm{~s}^{-1}$ ).

\subsubsection{Sediment}

The sediment of the mineral adjusted milks was determined by transferring samples $(50 \mathrm{~mL})$ into graduated conical centrifuge tubes and centrifuging them for $10 \mathrm{~min}$ at approximately $200 \times g($ Beckman J6-HC centrifuge JS 4.2 rotor, $800 \mathrm{rpm}$ ). Following centrifugation, the bulk of the supernatant liquid was removed by aspiration and any pellet re-suspended in water to a total volume of $50 \mathrm{~mL}$, mixed well and re-centrifuged. The volume of any sediment was determined using the graduations on the tube.

\subsubsection{Assessment of heat stability}

Milks were tested for the ability to withstand high-heat treatment conditions. Heat stability tests were conducted by heating samples of the reconstituted powders or adjusted milks ( $100 \mathrm{~mL}$ in glass beakers) in a waterbath $\left(90^{\circ} \mathrm{C}\right)$ for $10 \mathrm{~min}$ with continual stirring. The samples were then cooled to room temperature for analysis.

Following heating, the milks were observed and their viscosity and sediment determined as described above. In this work, a viscosity reading of up to $2.5 \mathrm{mPa} \cdot \mathrm{s}$ at room temperature after heat treatment has been used as an indication that the milk is "heat stable". That is, there has been minimal change compared to unheated milk. In practice, milks were either quite stable, with a viscosity between 2.0 and $2.5 \mathrm{mPa} \cdot \mathrm{s}$ or quite unstable with obvious precipitates, sediment or excessive thickening. Occa- sional samples were observed at the margins of stability with viscosities greater than $2.5 \mathrm{mPa} \cdot \mathrm{s}$ without gross coagulation. However, in designing fortification strategies for production of heat stable calcium-fortified milks, these margins should be avoided.

\subsubsection{Ultracentrifugation of milk to obtain supernatant fractions}

Unheated, mineral adjusted and control milks were separated into supernatant and pellet phases by centrifugation at $77000 \times g$ for $90 \mathrm{~min}$ at room temperature (30 700 rpm, Beckman L8-80M centrifuge 55.1 Ti rotor, Beckman Coulter, Sydney, Australia). Under these conditions, the composition of the supernatant phase can be viewed as an empirical guide to the composition of the serum phase of the original milk. Following centrifugation, supernatants were collected, weighed, and pooled for analysis.

\subsubsection{Capillary zone electrophoresis}

Capillary zone electrophoresis was performed using a Beckman P/ACE 5510 system based on the method of Kanning, Casella and Olieman [15]. Aliquots (1 mL) of milk or the supernatants from adjusted milks were lyophilised and then re-dissolved in sample buffer: (urea $\left(6 \mathrm{~mol} \cdot \mathrm{L}^{-1}\right) /$ trisodium citrate $\left(5 \mathrm{mmol} \cdot \mathrm{L}^{-1}\right) /$ dithiothreitol $\left.\left(1 \mathrm{mmol} \cdot \mathrm{L}^{-1}\right), \mathrm{pH} 8.0,500 \mu \mathrm{L}\right)$ and an internal standard $(20 \mu \mathrm{L}$ Gly-Tyr dipeptide $10 \mathrm{mg} \cdot \mathrm{mL}^{-1}$ solution) added, then incubated at $37{ }^{\circ} \mathrm{C}$ for at least $30 \mathrm{~min}$ before injection into the capillary. Samples were eluted with running buffer: urea $\left(6 \mathrm{~mol} \cdot \mathrm{L}^{-1}\right) /$ trisodium citrate $\left(20 \mathrm{mmol} \cdot \mathrm{L}^{-1}\right) / \mathrm{MHEC}$ $\left(0.5 \mathrm{~g} \cdot \mathrm{kg}^{-1}\right), \mathrm{pH} 3.0$. For assignation of peaks, a standard solution of the milk proteins $\alpha$-lactalbumin $\left(3 \mathrm{mg} \cdot \mathrm{mL}^{-1}\right), \beta$-lactoglobulin (5 $\left.\mathrm{mg} \cdot \mathrm{mL}^{-1}\right), \alpha$-casein $\left(10 \mathrm{mg} \cdot \mathrm{mL}^{-1}\right), \beta$ casein $\left(10 \mathrm{mg} \cdot \mathrm{mL}^{-1}\right), \kappa$-casein $\left(5 \mathrm{mg} \cdot \mathrm{mL}^{-1}\right)$ was run under the same conditions used for experimental samples.

\subsubsection{Production of calcium-fortified milk powders}

Full-cream milk was obtained from Tatura Milk industries (Tatura Vic., Australia) 
on three occasions. For production of skim milk powders, the milk was skimmed at Food Science Australia to produce skim milks with $89.8,91.3$ and $88.4 \mathrm{~g} \cdot \mathrm{kg}^{-1}$ milk solids non-fat (msnf), respectively. The target fortification level was designed so the finished powder contains approximately $8 \mathrm{~g}$ added calcium per kg powder (equivalent to 20 mmol added calcium per litre of milk) by calculating the required level of salts as a proportion of the milk solids content of the base unfortified milk. Based on a natural milk calcium content of $30 \mathrm{mmol} \cdot \mathrm{L}^{-1}$ (1200 mg. $\left.\mathrm{L}^{-1}\right)$, this fortification level results in reconstituted skim milk solutions $(100 \mathrm{~g}$ solids $\cdot \mathrm{kg}^{-1}$ ) and full-cream milk solutions (125 g solids $\left.\cdot \mathrm{kg}^{-1}\right)$ with a calcium concentration of at least $50 \mathrm{mmol} \cdot \mathrm{L}^{-1}\left(2000 \mathrm{mg} \cdot \mathrm{L}^{-1}\right)$.

The full-cream milk was used directly or skimmed (Westphalia separator, model MN1254D). This milk was either processed directly without adjustment to produce control samples or supplemented as described below to produce fortified milks. The control or fortified milks were preheated as required $\left(72{ }^{\circ} \mathrm{C}\right.$ for $30 \mathrm{~s}$ for low-heat or $90{ }^{\circ} \mathrm{C}$ for $10 \mathrm{~min}$ for high-heat), then concentrated to approximately $450 \mathrm{~g}$ total solids $\cdot \mathrm{kg}^{-1}$ on a Niro triple-effect falling film evaporator. This concentrate was dried to milk powder in a Niro Production Minor drier (inlet temperature $185^{\circ} \mathrm{C}$, outlet temperature $80^{\circ} \mathrm{C}$ ).

In trial 1 , skim milk powders were produced by combining skim milk $(8.9 \%$ milk solids non-fat, msnf) with solutions of $\mathrm{K}_{3} \mathrm{PO}_{4}$ $\left(0.2 \mathrm{~mol} \cdot \mathrm{kg}^{-1}\right)$ then $\mathrm{CaCl}_{2}\left(0.2 \mathrm{~mol} \cdot \mathrm{kg}^{-1}\right)$ and coupled with $\mathrm{pH}$ adjustment with $\mathrm{HCl}$ $\left(1 \mathrm{~mol} \cdot \mathrm{L}^{-1}\right)$ to $\mathrm{pH} 7.1$ or a mixed solution of $\mathrm{NaH}_{2} \mathrm{PO}_{4}\left(0.2 \mathrm{~mol} \cdot \mathrm{kg}^{-1}\right)$ / $\mathrm{KOH}$ $\left(0.32 \mathrm{~mol} \cdot \mathrm{kg}^{-1}\right)$ and then $\mathrm{CaCl}_{2}\left(0.2 \mathrm{~mol} \cdot \mathrm{kg}^{-1}\right)$ solution coupled with $\mathrm{pH}$ adjustment with $\mathrm{NaOH}$ to $\mathrm{pH}$ 7.0. Batches of milk fortified by either strategy were given either a high or low pre-heat treatment and processed into powder as described above. For the production of full-cream milk powder, a mixed solution of $\mathrm{NaH}_{2} \mathrm{PO}_{4}\left(0.2 \mathrm{~mol} \cdot \mathrm{kg}^{-1}\right)$ / $\mathrm{KOH}\left(0.32 \mathrm{~mol} \cdot \mathrm{kg}^{-1}\right)$ and then a solution of $\mathrm{CaCl}_{2}\left(0.2 \mathrm{~mol} \cdot \mathrm{kg}^{-1}\right)$ were mixed with fullcream milk ( $89 \mathrm{~g} \mathrm{msnf} \cdot \mathrm{kg}^{-1}$ and $40 \mathrm{~g}$ fat $\left.\cdot \mathrm{kg}^{-1}\right)$. The $\mathrm{pH}$ of the final mixture was 6.9 before processing.
In trial 2, calcium-fortified skim milk powder was manufactured by adding a mixed solution of $\mathrm{NaH}_{2} \mathrm{PO}_{4}\left(0.2 \mathrm{~mol} \cdot \mathrm{kg}^{-1}\right)$ and $\mathrm{KOH}\left(0.32 \mathrm{~mol} \cdot \mathrm{kg}^{-1}\right)$ to skim milk $(91.3 \mathrm{~g}$ $\mathrm{msnf} \cdot \mathrm{kg}^{-1}$ ) with stirring, followed by a $\mathrm{CaCl}_{2}$ solution $\left(0.2 \mathrm{~mol} \cdot \mathrm{kg}^{-1}\right)$. Following these additions, the $\mathrm{pH}$ of the mix was 6.936.94. The $\mathrm{pH}$ of the mixture was adjusted to $\mathrm{pH} 6.99$ by the addition of $1 \mathrm{~mol} \cdot \mathrm{L}^{-1}$ $\mathrm{KOH}$. The mixture was then stirred for $30 \mathrm{~min}$. Following the stirring period, the $\mathrm{pH}$ was measured as 6.95. Batches of this mix were then given either a high or low pre-heat treatment and processed into powder as described above

In trial 3, calcium-fortified skim milk powder was manufactured by adding solutions of $\mathrm{NaH}_{2} \mathrm{PO}_{4} \quad\left(0.2 \mathrm{~mol} \cdot \mathrm{kg}^{-1}\right) / \mathrm{KOH}$ $\left(0.36 \mathrm{~mol} \cdot \mathrm{kg}^{-1}\right)$ to skim milk with stirring followed by a solution of $\mathrm{CaCl}_{2}\left(0.2 \mathrm{~mol} \cdot \mathrm{kg}^{-1}\right)$. Following these additions, the $\mathrm{pH}$ of the mix was 7.0. This mix was then given a lowheat pre-treatment and processed into powder, as described above.

There was no coagulation or excessive thickening of any of the calcium-fortified milks following the high heat treatment.

\section{RESULTS AND DISCUSSION}

\subsection{Effect of mineral adjustments on the $\mathrm{pH}$ calcium activity and heat stability of milk}

The average $\mathrm{pH}$ of solutions of reconstituted skim milk powder at $100 \mathrm{~g} \mathrm{msnf} \cdot \mathrm{kg}^{-1}$ was 6.67. Adding 10 or $20 \mathrm{mmol}$ calcium chloride per litre of milk caused the $\mathrm{pH}$ of solutions to fall to 6.37 and 6.19 , respectively. This is the result of changes in the equilibria of the milk salt system and ionic strength with consequent displacement of $\mathrm{H}^{+}$. The natural free calcium level of skim milk at $10 \%$ solids is $\sim 2 \mathrm{mmol} \cdot \mathrm{L}^{-1}$. Addition of 10 or $20 \mathrm{mmol}$ calcium per litre caused free calcium to rise to $6.5 \mathrm{mmol} \cdot \mathrm{L}^{-1}$ and $13.6 \mathrm{mmol} \cdot \mathrm{L}^{-1}$, respectively, indicating that that the added salts caused changes to the equilibria of the milk salt system. Without further additions or adjustments, milk with either 10 or $20 \mathrm{mmol}$ added calcium per litre was not heat stable. 


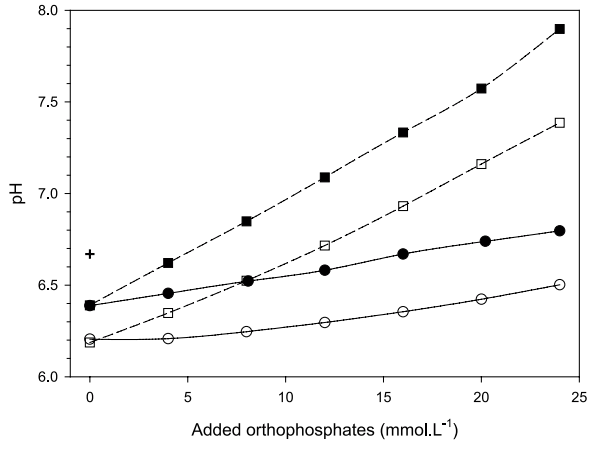

Figure 1. Relationship between $\mathrm{pH}$ and level of added orthophosphates in fortified low-heat skim milk powder solutions ( $\left.100 \mathrm{~g} \mathrm{msnf} \cdot \mathrm{kg}^{-1}\right)$ : milk with added $\mathrm{CaCl}_{2}\left(20 \mathrm{mmol} \cdot \mathrm{L}^{-1}\right)$ and $\mathrm{K}_{3} \mathrm{PO}_{4}(\square)$, milk with added $\mathrm{CaCl}_{2}$ $\left(20 \mathrm{mmol} \cdot \mathrm{L}^{-1}\right)$ and $\mathrm{Na}_{2} \mathrm{HPO}_{4}(\mathrm{O})$, milk with added $\mathrm{CaCl}_{2}\left(10 \mathrm{mmol} \cdot \mathrm{L}^{-1}\right)$ and $\mathrm{K}_{3} \mathrm{PO}_{4}(\mathbf{\square})$, milk with added $\mathrm{CaCl}_{2}\left(10 \mathrm{mmol} \cdot \mathrm{L}^{-1}\right)$ and $\mathrm{Na}_{2} \mathrm{HPO}_{4}(\bullet)$. The average $\mathrm{pH}$ of skim milk solutions $\left(100 \mathrm{~g} \mathrm{msnf}^{\circ} \mathrm{kg}^{-1}\right)$ is shown $(+)$ for comparison.

The addition of $\mathrm{Na}_{2} \mathrm{HPO}_{4}$ or $\mathrm{K}_{3} \mathrm{PO}_{4}$ to milk with 10 or 20 mmol added calcium per litre of milk caused the $\mathrm{pH}$ to rise, as shown in Figure 1. As $\mathrm{K}_{3} \mathrm{PO}_{4}$ is the stronger base, it has a greater effect than added $\mathrm{Na}_{2} \mathrm{HPO}_{4}$. The orthophosphate anions can interact with $\mathrm{H}^{+}$; this will cause a change in the $\mathrm{pH}$. They can also interact with free $\mathrm{Ca}^{2+}$ causing a re-arrangement of the concentrations of ions in milk. This is reflected in a fall in free calcium ion activity, as shown in Figure 2 . The relationship between free calcium ion activity or $\mathrm{pH}$ and heat stability in milk solutions fortified with equimolar levels of calcium chloride and orthophosphates is represented in Figures 3 and 4 . The range of $\mathrm{pH}$ was obtained through the addition of $\mathrm{NaOH}$ or by varying the ratio of $\mathrm{Na}_{3} \mathrm{PO}_{4}$ to $\mathrm{Na}_{2} \mathrm{HPO}_{4}$ to $\mathrm{NaH}_{2} \mathrm{PO}_{4}$. In milk with either 10 or $20 \mathrm{mmol}$ added calcium per litre in combination with added orthophosphates, heat stability was lost, marked by a sharp rise in post-heat viscosity, in milks with a pre-heat $\mathrm{pH}$ value below 6.5 or a free calcium ion activity greater than approximately $3.3 \mathrm{mmol} \cdot \mathrm{L}^{-1}$. At both added calcium levels, the relationships between

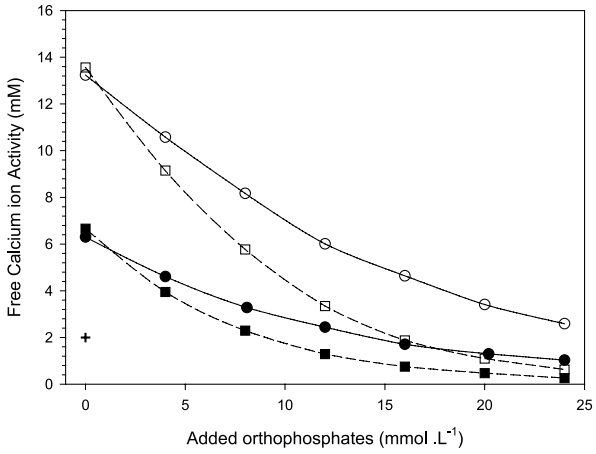

Figure 2. Relationship between free calcium ion activity and level of added orthophosphates in fortified low-heat skim milk powder solutions ( $\left.100 \mathrm{~g} \mathrm{msnf} \cdot \mathrm{kg}^{-1}\right)$ : milk with added $\mathrm{CaCl}_{2}$ (20 mmol. $\mathrm{L}^{-1}$ ) and $\mathrm{K}_{3} \mathrm{PO}_{4}(\square)$, milk with added $\mathrm{CaCl}_{2}\left(20 \mathrm{mmol} \cdot \mathrm{L}^{-1}\right)$ and $\mathrm{Na}_{2} \mathrm{HPO}_{4}(\mathrm{O})$, milk with added $\mathrm{CaCl}_{2}\left(10 \mathrm{mmol} \cdot \mathrm{L}^{-1}\right)$ and $\mathrm{K}_{3} \mathrm{PO}_{4}(\mathbf{\square})$, milk with added $\mathrm{CaCl}_{2}$ $\left(10 \mathrm{mmol} \cdot \mathrm{L}^{-1}\right)$ and $\mathrm{Na}_{2} \mathrm{HPO}_{4}(\bullet)$. The average free calcium ion activity of skim milk solutions (100 $\left.\mathrm{g} \mathrm{msnf} \cdot \mathrm{kg}^{-1}\right)$ is shown (+) for comparison.

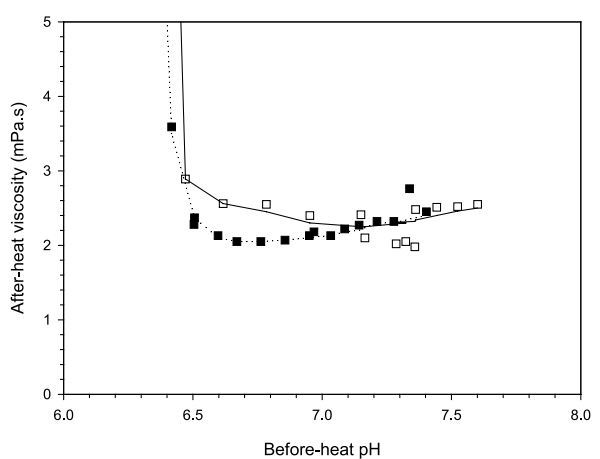

Figure 3. Relationship between $\mathrm{pH}$ before heating and viscosity after heating of low-heat skim milk powder solutions ( $\left.100 \mathrm{~g} \mathrm{msnf} \cdot \mathrm{kg}^{-1}\right)$ fortified with $\mathrm{CaCl}_{2}$ and equimolar levels of orthophosphates: milk with added $\mathrm{CaCl}_{2}\left(20 \mathrm{mmol} \cdot \mathrm{L}^{-1}\right)$ and orthophosphates $\left(20 \mathrm{mmol} \cdot \mathrm{L}^{-1}\right)(\square)$, milk with added $\mathrm{CaCl}_{2}\left(10 \mathrm{mmol} \cdot \mathrm{L}^{-1}\right)$ and orthophosphates $\left(10 \mathrm{mmol} \cdot \mathrm{L}^{-1}\right)(\square)$. The range of $\mathrm{pH}$ was obtained through the addition of $\mathrm{NaOH}$ or by varying the ratio of $\mathrm{Na}_{3} \mathrm{PO}_{4}$ to $\mathrm{Na}_{2} \mathrm{HPO}_{4}$ to $\mathrm{NaH}_{2} \mathrm{PO}_{4}$.

$\mathrm{pH}$ and free calcium followed a similar pattern (Fig. 5). 


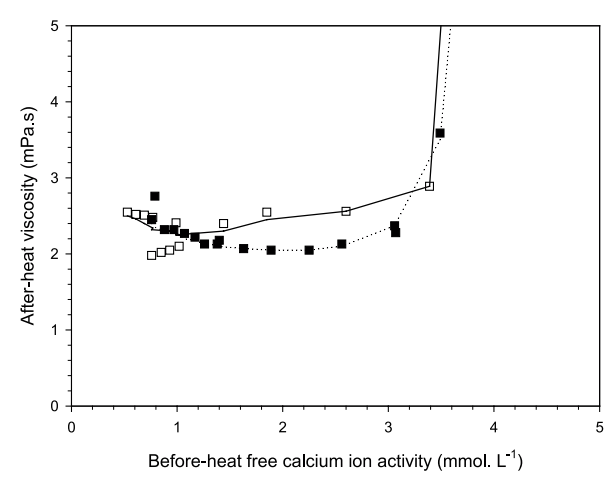

Figure 4. Relationship between free calcium ion activity before heating and viscosity after heating of low-heat skim milk powder solutions $(100 \mathrm{~g}$ msnf $\cdot \mathrm{kg}^{-1}$ ) fortified with $\mathrm{CaCl}_{2}$ and equimolar levels of orthophosphates: milk with added $\mathrm{CaCl}_{2} \quad\left(20 \mathrm{mmol} \cdot \mathrm{L}^{-1}\right)$ and orthophosphates $\left(20 \mathrm{mmol} \cdot \mathrm{L}^{-1}\right)(\square)$, milk with added $\mathrm{CaCl}_{2}$ $\left(10 \mathrm{mmol} \cdot \mathrm{L}^{-1}\right)$ and orthophosphates $\left(10 \mathrm{mmol} \cdot \mathrm{L}^{-1}\right)$ (घ). The range of $\mathrm{pH}$ was obtained through the addition of $\mathrm{NaOH}$ or by varying the ratio of $\mathrm{Na}_{3} \mathrm{PO}_{4}$ to $\mathrm{Na}_{2} \mathrm{HPO}_{4}$ to $\mathrm{NaH}_{2} \mathrm{PO}_{4}$.

These experiments suggested that calcium-fortified milks with improved heat stability could be achieved through control of calcium activity and $\mathrm{pH}$ with the use of soluble calcium salts in combination with orthophosphates.

\subsection{Effect of mineral adjustments on the phase distribution of calcium and protein in milks}

To identify the effects of additions of calcium and other added salts on the distribution of salts and protein between the micellar and serum phases, reconstituted low-heat skim milks ( $10 \%$ msnf) were formulated with added calcium $\left(20 \mathrm{mmol} \cdot \mathrm{L}^{-1}\right)$ only, or with added calcium $\left(20 \mathrm{mmol} \cdot \mathrm{L}^{-1}\right)$ in combination with added orthophosphate $\left(20 \mathrm{mmol} \cdot \mathrm{L}^{-1}\right)$, citrate $\left(20 \mathrm{mmol} \cdot \mathrm{L}^{-1}\right)$, pyrophosphate $\left(4 \mathrm{mmol} \cdot \mathrm{L}^{-1}\right)$, tripolyphosphate $\left(8 \mathrm{mmol} \cdot \mathrm{L}^{-1}\right)$ or polyphosphate $\left(1.5 \mathrm{~g} \cdot \mathrm{kg}^{-1}\right)$. All were adjusted to $\mathrm{pH} 7.0$ before centrifugation. An unadjusted skim milk at pH 6.7 was also analysed. The milks were centrifuged and the supernatants (representing

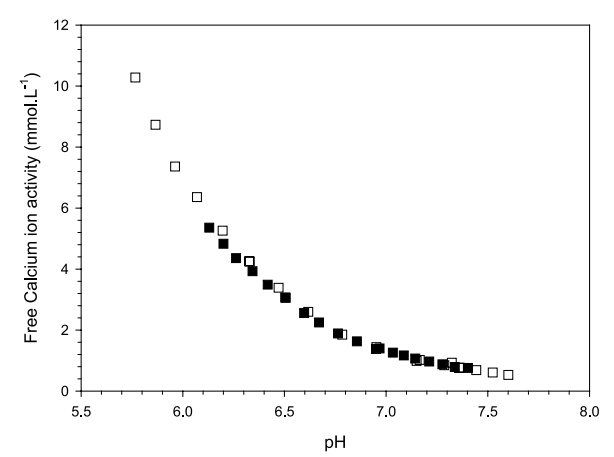

Figure 5. Relationship between $\mathrm{pH}$ and free calcium ion activity in low-heat skim milk powder solutions $\left(100 \mathrm{~g} \mathrm{msnf} \cdot \mathrm{kg}^{-1}\right)$ fortified with $\mathrm{CaCl}_{2}$ and equimolar levels of orthophosphates: milk with added $\mathrm{CaCl}_{2}\left(20 \mathrm{mmol} \cdot \mathrm{L}^{-1}\right)$ and orthophosphates $\left(20 \mathrm{mmol} \cdot \mathrm{L}^{-1}\right)(\square)$, milk with added $\mathrm{CaCl}_{2}\left(10 \mathrm{mmol} \cdot \mathrm{L}^{-1}\right)$ and orthophosphates $\left(10 \mathrm{mmol} \cdot \mathrm{L}^{-1}\right)(\boldsymbol{\square})$. The range of $\mathrm{pH}$ was obtained through the addition of $\mathrm{NaOH}$ or by varying the ratio of $\mathrm{Na}_{3} \mathrm{PO}_{4}$ to $\mathrm{Na}_{2} \mathrm{HPO}_{4}$ to $\mathrm{NaH}_{2} \mathrm{PO}_{4}$.

the serum phase of the milks) obtained were analysed for calcium, and total and individual proteins. For comparison, the relative calcium concentration of the supernatant, as a percentage of the complete milk has been calculated (Tab. I).

For skim milk that had not been adjusted in any way, the calcium concentration of the supernatant phase of the milk was of the order of one quarter of the concentration in the total milk. The addition of calcium chloride alone to the milk, while increasing the total calcium concentration of both the milk and the serum phase, caused little change in the proportion of calcium in the supernatant. The addition of orthophosphate and calcium caused a considerable reduction in the relative proportion of calcium in the supernatant. This implies that the addition of orthophosphates with calcium causes a greater proportional transfer of calcium into the sedimentable phase of the milk. The addition of citrate, at a concentration equivalent to that of added orthophosphate, caused a major shift in the distribution with the relative concentration of the supernatant 
Table I. Effect of addition of $20 \mathrm{mmol} \cdot \mathrm{L}^{-1}$ calcium or $20 \mathrm{mmol} \cdot \mathrm{L}^{-1}$ calcium in combination with a range of calcium-modifying salts on the distribution of calcium and protein into the supernatant $(77000 \times g / 90 \mathrm{~min})$ phase of fortified reconstituted low-heat skim milk (data are shown as mean \pm standard deviation).

\begin{tabular}{|c|c|c|c|c|c|c|c|}
\hline Additive & $\mathrm{pH}$ & $\begin{array}{l}\text { Total milk } \\
\text { calcium } \\
\left(\mathrm{mmol} \cdot \mathrm{L}^{-1}\right)\end{array}$ & $\begin{array}{l}\text { Supernatant } \\
\text { calcium } \\
\left(\mathrm{mmol} \cdot \mathrm{L}^{-1}\right)\end{array}$ & $\begin{array}{l}\text { Supernatant } \\
\text { calcium as \% } \\
\text { of total milk }\end{array}$ & $\begin{array}{c}\text { Total milk } \\
\text { protein } \\
\left(\mathrm{g} \cdot \mathrm{kg}^{-1}\right)\end{array}$ & $\begin{array}{c}\text { Supernatant } \\
\text { protein } \\
\left(\mathrm{g} \cdot \mathrm{kg}^{-1}\right)\end{array}$ & $\begin{array}{l}\text { Supernatant } \\
\text { protein as \% } \\
\text { of total milk }\end{array}$ \\
\hline None & 6.7 & $30.8 \pm 0.14$ & $7.9 \pm 0.28$ & $25.6 \%$ & $31.4 \pm 0.4$ & $6.7 \pm 0.1$ & $21.4 \%$ \\
\hline $\mathrm{CaCl}_{2}\left(20 \mathrm{mmol} \cdot \mathrm{L}^{-1}\right)$ & 7.0 & $53.5 \pm 2.12$ & $13.7 \pm 1.84$ & $25.6 \%$ & $33.3 \pm 3.1$ & $5.5 \pm 0.4$ & $16.4 \%$ \\
\hline $\begin{array}{l}\mathrm{CaCl}_{2}\left(20 \mathrm{mmol} \cdot \mathrm{L}^{-1}\right) \text { and } \\
\text { orthophosphate }\left(20 \mathrm{mmol} \cdot \mathrm{L}^{-1}\right)\end{array}$ & 7.0 & $52.2 \pm 1.06$ & $7.1 \pm 0.78$ & $13.7 \%$ & $31.7 \pm 0.8$ & $5.5 \pm 0.3$ & $17.4 \%$ \\
\hline $\begin{array}{l}\mathrm{CaCl}_{2}\left(20 \mathrm{mmol} \cdot \mathrm{L}^{-1}\right) \text { and } \\
\text { pyrophosphate }\left(4 \mathrm{mmol} \cdot \mathrm{L}^{-1}\right)\end{array}$ & 7.0 & $51.4 \pm 0.21$ & $10.6 \pm 2.12$ & $20.6 \%$ & $29.8 \pm 1.6$ & $5.5 \pm 0.4$ & $18.5 \%$ \\
\hline $\begin{array}{l}\mathrm{CaCl}_{2}\left(20 \mathrm{mmol} \cdot \mathrm{L}^{-1}\right) \text { and } \\
\text { tripolyphosphate }\left(8 \mathrm{mmol} \cdot \mathrm{L}^{-1}\right)\end{array}$ & 7.0 & $51.8 \pm 0.35$ & $9.2 \pm 0.64$ & $17.8 \%$ & $31.5 \pm 0.8$ & $9.1 \pm 1.5$ & $28.8 \%$ \\
\hline $\begin{array}{l}\mathrm{CaCl}_{2}\left(20 \mathrm{mmol} \cdot \mathrm{L}^{-1}\right) \text { and } \\
\text { polyphosphate }\left(1.5 \mathrm{~g} \cdot \mathrm{kg}^{-1}\right)\end{array}$ & 7.0 & $53.6 \pm 2.62$ & $10.5 \pm 1.84$ & $19.6 \%$ & $32.8 \pm 1.2$ & $6.2 \pm 1.1$ & $18.8 \%$ \\
\hline $\begin{array}{l}\mathrm{CaCl}_{2}\left(20 \mathrm{mmol} \cdot \mathrm{L}^{-1}\right) \text { and } \\
\text { citrate }\left(20 \mathrm{mmol} \cdot \mathrm{L}^{-1}\right)\end{array}$ & 7.0 & $51.3 \pm 1.34$ & $30.9 \pm 3.11$ & $60.2 \%$ & $30.5 \pm 1.6$ & $7.8 \pm 0.6$ & $25.6 \%$ \\
\hline
\end{tabular}

fraction, increasing supernatant calcium to more than twice that seen in either normal milk or milk with added calcium alone. Longer chain phosphates; pyrophosphate $\left(\mathrm{P}_{2} \mathrm{O}_{5}\right)$, tripolyphosphate $\left(\mathrm{P}_{3} \mathrm{O}_{10}\right)$ or polyphosphate $\left(\mathrm{P}_{n} \mathrm{O}_{3 n+1}, n=10 \sim 12\right)$, added at the concentrations shown, caused a reduction in the relative calcium concentration of the supernatant.

As in the case of the calcium analysis, the relative protein concentration of the supernatant, as a percentage of the complete milk was calculated. In milk without additives, the protein concentration in the milk serum was about $20 \%$ of the protein concentration of the total milk. The majority of this protein is $\beta$-lactoglobulin and $\alpha$-lactalbumin, but a small proportion is casein. These serum caseins occur in equilibrium with the micellar caseins. The addition of calcium alone, or calcium and orthophosphate to the milk caused a reduction in the relative concentration of protein in the supernatant implying that the calcium, ortho-phosphate, and protein migrate together into the micellar phase of phase. Addition of pyro-phosphate or polyphosphate in combination with calcium had a similar effect to the addition of ortho-phosphate and calcium, however, the use of tripoly-phosphate or citrate in combination with added calcium, caused an increase in the relative concentration of protein in the supernatant.

To investigate which protein components migrated between phases, the centrifugal supernatants were analysed by capillary electrophoresis. A representative set of results are shown in Figure 6. A set of standard milk proteins (trace a), and the seven experimental treatments (traces $\mathrm{b}-\mathrm{h}$ ) run under the same conditions are shown. The peaks attributable to the different standard milk proteins have been assigned according to their comparison with retention times and patterns obtained when run individually. It should be noted that few if any of the standard proteins migrated as a single peak when analysed by this procedure. Reasons for this include genetic variation and differences in the post-translational modification of the proteins (glycosylation, phosphorylation). There is also marked spreading or broadening 
$\mathrm{L}$

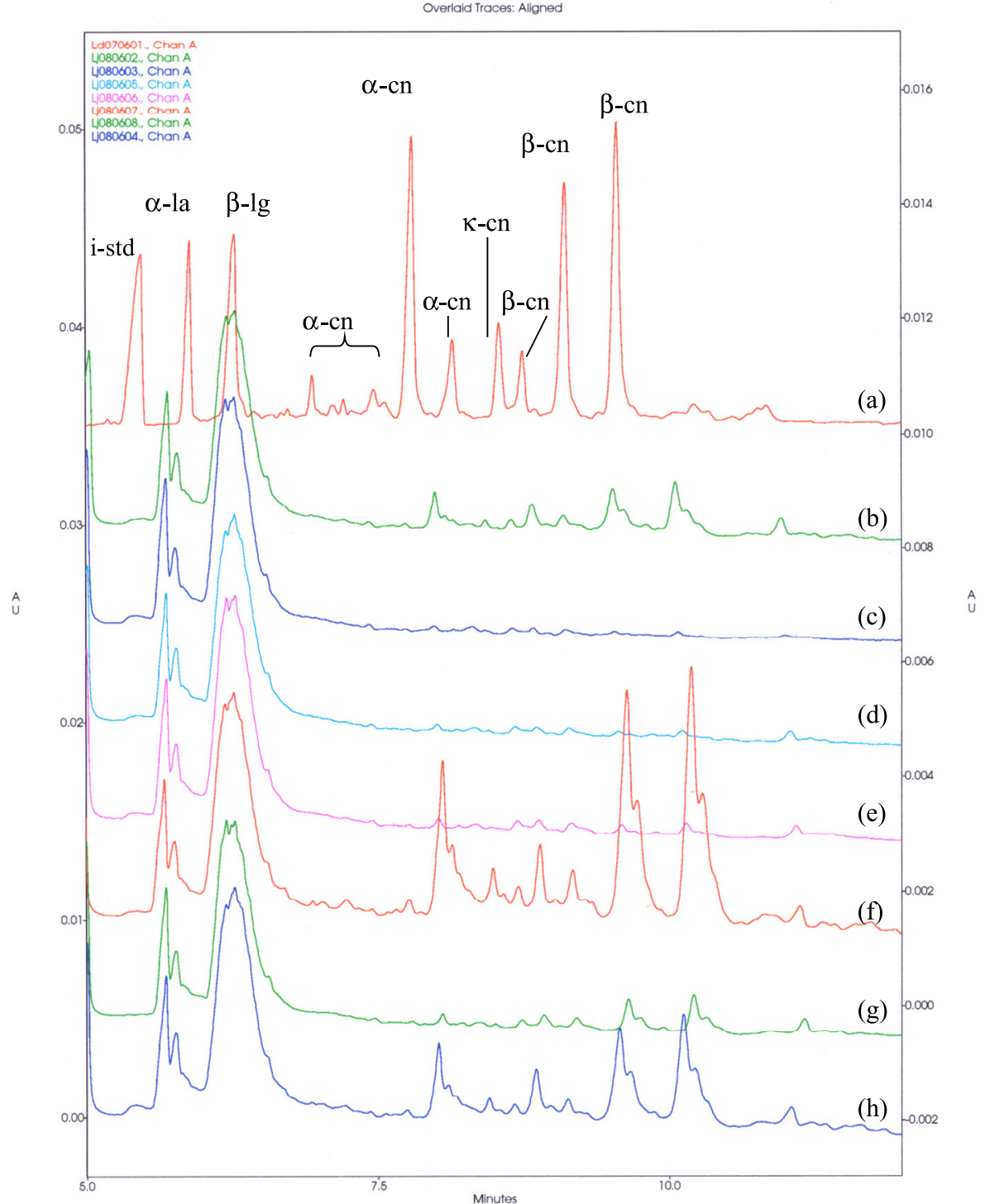

Figure 6. Capillary electrophoresis analysis of supernatant fractions of reconstituted low-heat skim milk (100 g msnf $\cdot \mathrm{kg}^{-1}$, $\left.\mathrm{pH} 7.0\right)$ with added calcium and a range of calcium-modifying agents: (a) standards: $i$-std: Gly-Tyr dipeptide; $\alpha$-la: $\alpha$-lactalbumin; $\beta$-lg: $\beta$-lactoglobulin; $\alpha$-cn: $\alpha$-casein; $\beta$-cn: $\beta$-casein; $\kappa$-cn: $\kappa$-casein. (b) Supernatant fraction from skim milk pH 6.7. (c) Supernatant fraction from skim milk with added $\mathrm{CaCl}_{2}\left(20 \mathrm{mmol} \cdot \mathrm{L}^{-1}\right)$. (d) Supernatant fraction from skim milk with added $\mathrm{CaCl}_{2}\left(20 \mathrm{mmol} \cdot \mathrm{L}^{-1}\right)$ and orthophosphate $\left(20 \mathrm{mmol} \cdot \mathrm{L}^{-1}\right)$. (e) Supernatant fraction from skim milk with added $\mathrm{CaCl}_{2}\left(20 \mathrm{mmol} \cdot \mathrm{L}^{-1}\right)$ and pyrophosphate $\left(4 \mathrm{mmol} \cdot \mathrm{L}^{-1}\right)$. (f) Supernatant fraction from skim milk with added $\mathrm{CaCl}_{2}\left(20 \mathrm{mmol} \cdot \mathrm{L}^{-1}\right)$ and tripolyphosphate $\left(8 \mathrm{mmol} \cdot \mathrm{L}^{-1}\right)$. (g) Supernatant fraction from skim milk with added $\mathrm{CaCl}_{2}\left(20 \mathrm{mmol} \cdot \mathrm{L}^{-1}\right)$ and Calgon $\mathrm{T}\left(1.5 \mathrm{~g} \cdot \mathrm{kg}^{-1}\right)$. (h) Supernatant fraction from skim milk with added $\mathrm{CaCl}_{2}\left(20 \mathrm{mmol} \cdot \mathrm{L}^{-1}\right)$ and citrate $\left(20 \mathrm{mmol} \cdot \mathrm{L}^{-1}\right)$. 
of some peaks in the experimental samples. This may be the result of proteolytic activity in the original milk, or of the heat treatment given during powder manufacture. These aspects of the procedure make it difficult to obtain reliable quantitative data. However, for initial qualitative analysis, the traces may be considered in two general regions; the early eluting $(<7.0 \mathrm{~min})$ whey proteins, ( $\beta$-lactoglobulin and $\alpha$-lactalbumin), then the later (>7.5 $\mathrm{min})$ caseins.

As would be expected, there was little change in the proportions of the peaks in the $\beta$-lactoglobulin and $\alpha$-lactalbumin regions of the electrophoretograms with any of the treatments (traces $b-h)$. This indicates that these proteins, which form the majority of the serum proteins, were not redistributed between serum and micellar phases. There were however considerable changes in the casein region. In general, the patterns shown mimic the changes observed in the analysis of protein nitrogen. Adding calcium (trace c) caused a reduction in the supernatant casein concentration compared to the supernatant from unmodified skim milk (trace $b$ ). When orthophosphate (trace d) or pyrophosphate (trace e) were added together with the calcium, a reduction in serum casein was also observed. Compared to the effect of calcium alone or calcium in combination with orthophosphate, the addition of calcium in combination with tripolyphosphate (trace f), polyphosphate (trace g) and citrate (trace h) all caused an increase in the levels of the caseins in the supernatants to varying degrees.

The differences in distribution between the serum and micellar phases of milk of both calcium and protein demonstrate that there are clearly identifiable differences in the effects caused by the different calciumcomplexing agents in combination with added calcium chloride. When calcium-fortified milks are produced by the use of a combination of calcium and orthophosphates, these milks can be differentiated from fortified milks made with calcium in combination with other typically used agents such as citrate, through an evaluation of the protein contents of the supernatant phases.

The changes in serum calcium and protein caused by the addition of orthophosphate in combination with calcium suggest that serum caseins combine with added calcium to add to existing micelles or create new micellelike aggregates in the presence of added orthophosphates. In contrast, added citrate or tripolyphosphate caused a markedly different distribution of calcium and protein compared to orthophosphate, suggesting that they cause a disintegration of the micelles. The other phosphates, i.e. pyro- or polyphosphate in combination with calcium were not as effective as orthophosphate for shifting protein out of the serum phase of milk.

Based on the information above, a strategy based on addition of calcium chloride in combination with orthophosphate for the production of calcium-fortified milk powders was examined.

\subsection{Composition and properties of calcium-fortified milk powders and reconstituted milks}

The composition of the calcium-fortified powders are given in Tables II and III. As expected, the calcium-fortified powders had a reduced protein content compared to the control powders because the added calcium and orthophosphate salts comprise part of the solids in the final powder. The calcium-fortified powders also had a higher level of protein soluble at $\mathrm{pH}$ 4.6. The increase in the level of protein soluble at $\mathrm{pH}$ 4.6 in milks with added salts suggests that not all the caseins are precipitated at $\mathrm{pH}$ 4.6. Previous research has shown that increasing $\mathrm{CaCl}_{2}$ from 10 to $100 \mathrm{mmol} \cdot \mathrm{L}^{-1}$ decreased the highest $\mathrm{pH}$ at which casein micelles coagulated from 5.0 to 3.8 , an effect that was explained by increased concentration of $\mathrm{H}^{+}$required to displace the hydrated $\mathrm{Ca}^{2+}$ associated with the protein $[5,16]$. The isoelectric point of casein has also been shown to be influenced by ionic strength [24]. The high heat treatment of the fortified milk powders caused a reduction in $\mathrm{pH}$ 4.6-soluble protein, as would be expected due to the denaturation of whey proteins.

The recovery of the calcium in the powders was calculated to be between 97 and $105 \%$ of the expected value. Free calcium activity in milks reconstituted from unadjusted and 
Table II. Characteristics of powders and reconstituted milks, Trial 1 (nd = not determined).

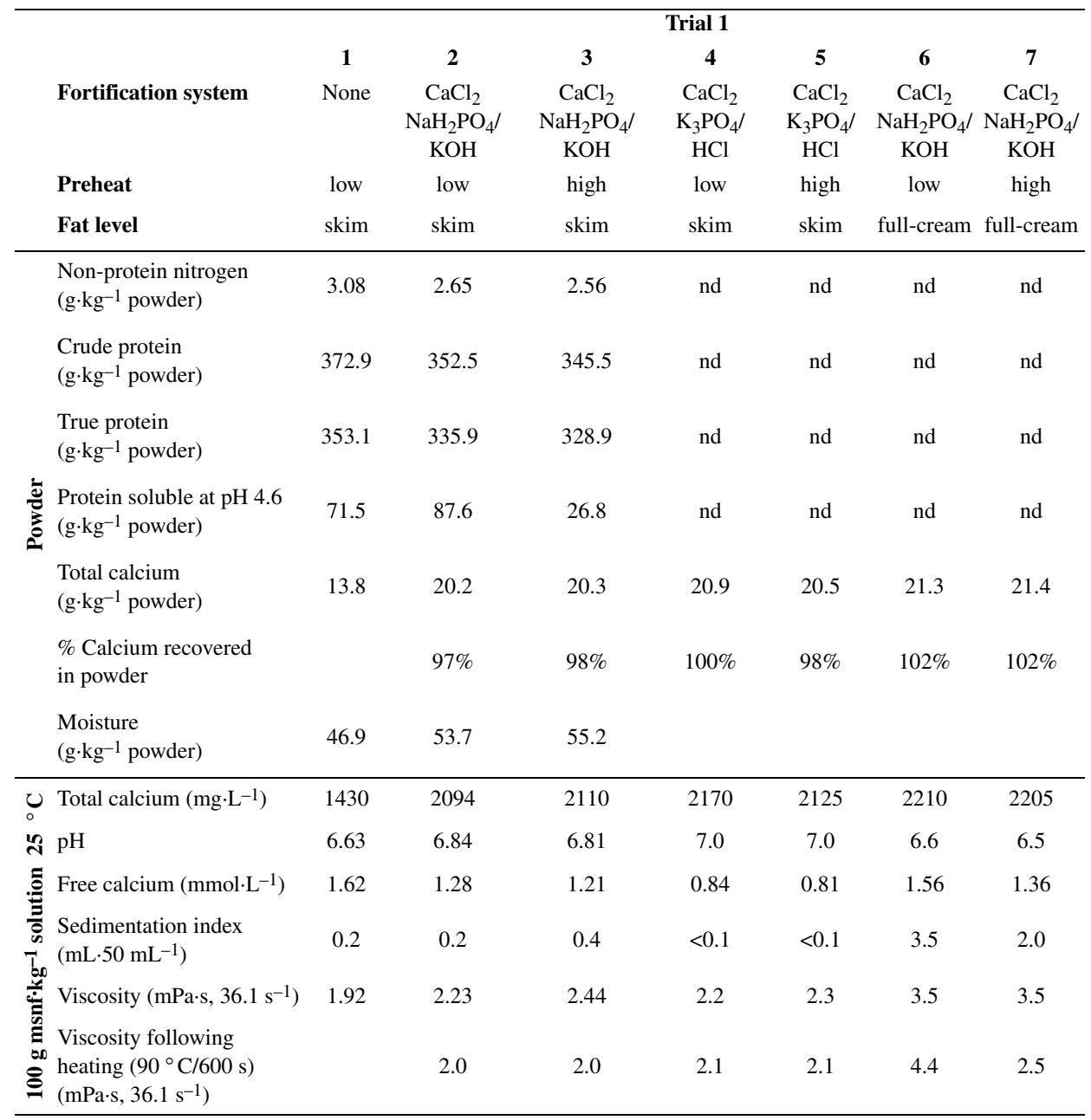

calcium-fortified powders was less than $2 \mathrm{mmol} \cdot \mathrm{L}^{-1}$ (pH range 6.70-6.75). The data also show that the powders can be reconstituted easily. The sediments were $<0.5 \mathrm{~mL}$ for calcium-fortified skim milk powders made from calcium-fortified milks ( $\mathrm{pH} 6.8$ 7.0) and between $2.0-3.5 \mathrm{~mL}$ for calciumfortified full-cream milk powders made from calcium-fortified milks ( $\mathrm{pH}$ 6.5-6.6). The high insolubility index results for the full-cream milk powders are also to be expected when the test is carried out at room temperature. The reconstituted milks had total calcium values between 2090 and $2300 \mathrm{mg} \cdot \mathrm{L}^{-1}$. Selected milks could withstand heating at $90{ }^{\circ} \mathrm{C} / 10 \mathrm{~min}$, the slight changes in viscosity on heating milks at $90{ }^{\circ} \mathrm{C} / 10$ min being considered minimal.

Orthophosphates in combination with calcium are highly effective for providing control of free calcium ion activity and heat stability of calcium-fortified milk powders. When used in the appropriate amounts with added calcium, their effect has a stabilising influence on micellar integrity that results in enhanced heat stability of the fortified milks. 
Table III. Characteristics of powders and reconstituted milks, Trials 2 and 3.

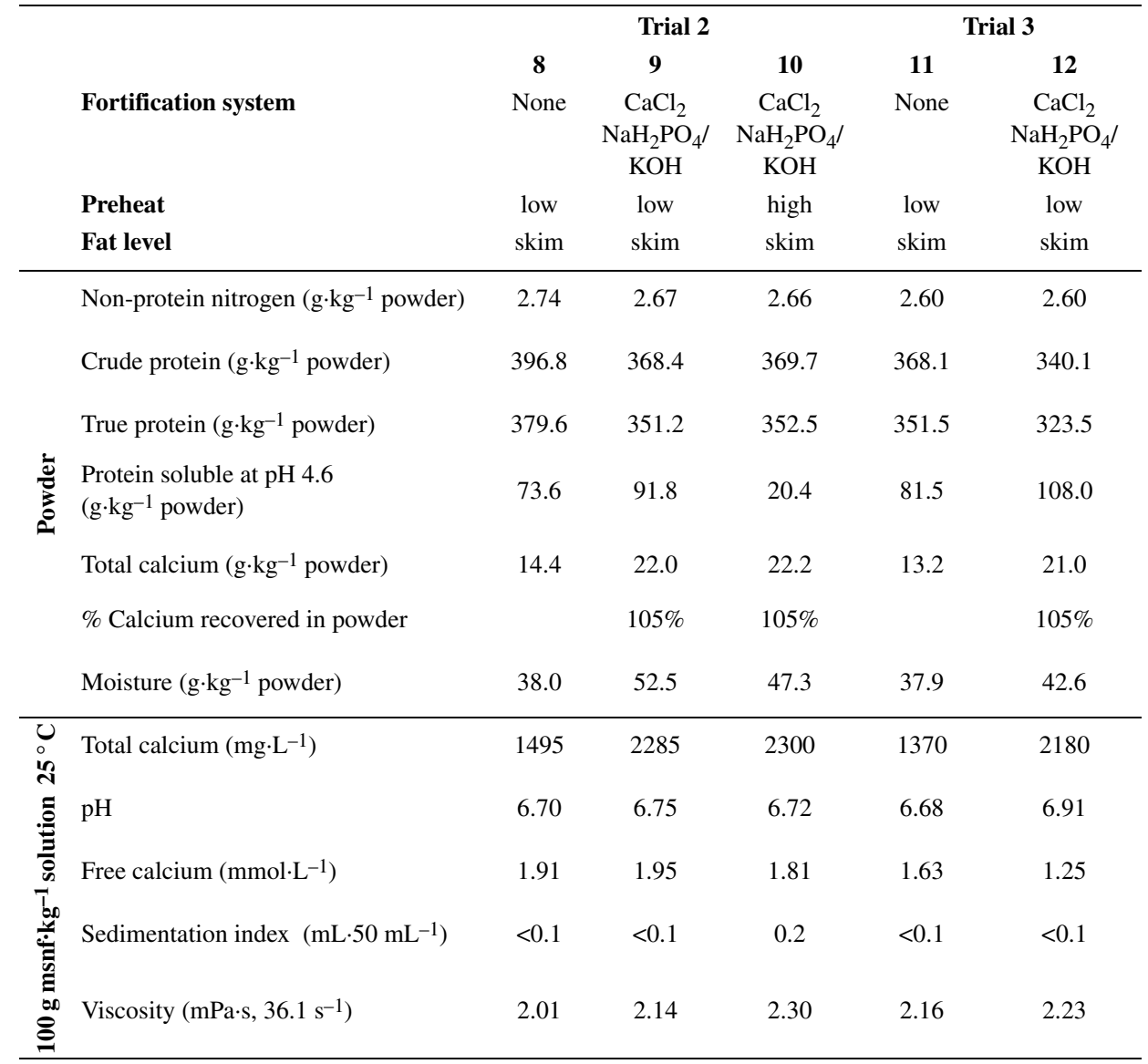

\section{CONCLUSION}

This research demonstrates that the heat stability of calcium-fortified milks is strongly related to the free calcium ion activity and the $\mathrm{pH}$ of the fortified milk and that these two factors are closely related. Orthophosphates in combination with calcium are highly effective for providing control of $\mathrm{pH}$, free calcium ion activity, and heat stability. It is suggested that this occurs through a unique mechanism which maintains micellar integrity and results in enhanced heat stability of the fortified milks.

This work has resulted in the development of a new, innovative and simple cost- effective strategy that enables fortification of milk and milk products [3]. The strategy has been successfully used for the production of calcium-fortified milk powders with a high level of added calcium (up to additional $8 \mathrm{~g}$ calcium per $\mathrm{kg}$ powder). It can be used for the production of both skim and full-cream milk powders with an increased calcium level. This method enables both highheat and low-heat powders to be produced.

Acknowledgements: We acknowledge support from the Dairy Research and Development Corporation (now Dairy Australia) and Food Science Australia and the assistance of A. Lawrence and L.J. Cheng in the pilot scale manufacture of milk powders. 


\section{REFERENCES}

[1] Augustin M.A., Clarke P.T., Effects of added salts on the heat stability of recombined concentrated milk, J. Dairy Res. 57 (1990) 213226.

[2] Augustin M.A., Clarke P.T., Calcium ion activities of cooled and aged reconstituted recombined milks, J. Dairy Res. 58 (1991) 219-229.

[3] Augustin M.A., Williams R.P.W., Nutritional mineral fortification of milk, Patent application WO 01/72135, 2001.

[4] Augustin M.A., Williams R.P.W., Technological aspects of calcium fortification of milk and dairy products, Food Austr. 54 (2002) 131-133.

[5] Bringe N.A., Kinsella J.E., Forces involved in the enzymatic and acidic coagulation of casein micelles, in: Hudson B.J.F. (Ed.), Developments in Food Proteins, Vol. 5, Elsevier Applied Science, London, UK, 1987, pp. 159-194.

[6] Flynn A., Cashman K., Calcium, in: Hurrell R. (Ed.), The mineral fortification of foods, Leatherhead International Ltd., Surrey, UK, 1999, pp. 18-53.

[7] Guamis-Lopez B., Quevedo-Terre J.M., Calcium enrichment of skimmed milk given UHT treatment, Alimentaria 271 (1996)79-82.

[8] Hamelijnck H.A.F., Lamers P.P.J.J., Mineral fortification of conventional foods, in: Hurrell R. (Ed.), The mineral fortification of foods, Leatherhead International Ltd., Surrey, UK, 1999, pp. 229-236.

[9] Hansen P.M.T., Fligner K., Process for the manufacture of a calcium fortified yoghurt with improved heat stability, Patent US 5449523, 1995.

[10] Harada H., Chihara S., Suginaka Y., Suido S., Kobayashi T., Process for making a calcium enriched milk, Patent US 4840814, 1989.

[11] Holt C., The milk salts: their secretion, concentrations and physical chemistry, in: Fox P.F. (Ed.), Developments in dairy chemistry, Vol. 3, Elsevier Applied Science, London, England, 1985, pp. 143-181.

[12] Holt C., Calcium phosphate nanoclusters and their applications, Patent application WO 01/ 44106, 2001.

[13] Holt C., Timmins P.A., Effington N., Leaver J., A core-shell model of calcium phosphate nanoclusters stabilised by $\beta$-casein phospho- peptides, derived from sedimentation equilibrium and small-angle $\mathrm{x}$-ray and neutron scattering experiments, Eur. J. Biochem. 252 (1998) 73-78.

[14] Jolivet E., Niesseron L., Schwan M., Milk base enriched in calcium and its preparation, Patent US 5987892, 1999.

[15] Kanning M., Casella M., Olieman C., Milk and soy proteins analysis using capillary zone electrophoresis, LC-GC International 6 (1993) 701-706.

[16] Kinsella J.E., Whitehead D.M., Brady J., Bringe N.A., Milk proteins: relationships of structure and function, in: Fox P.F. (Ed.), Developments in Dairy Chemistry, Vol. 4: Functional Milk Proteins, Elsevier Applied Science Publishers, London, England, 1989, pp. 55-95.

[17] Kuntz L.A., Boning up on calcium fortification, Food Prod. Design (May 1998) 75-99.

[18] O'Carroll P., Calcium, a growth story, World Food Ingredients (October/November 2000) 70-80.

[19] Potjewijd R., Calcium fortification of milk, World of Ingredients (December 1997) 46.

[20] Standards Association of Australia, Methods of chemical and physical testing for the dairying industry: General methods and principles - Determination of Nitrogen - Nitrogen fractions from milk (SAA AS 2300.1.2.2), 1988.

[21] Standards Association of Australia, Methods of chemical and physical testing for the dairying industry: General methods and principles - Determination of Nitrogen - Reference Kjeldahl method (SAA AS 2300.1.2.1), 1991.

[22] Schmidt D.G., Koops J., Westerbeek D., Properties of artificial casein micelles 1. Preparation, size distribution and composition, Neth. Milk Dairy J. 31 (1977) 328-341.

[23] Singh H., Creamer L.K., Heat stability of milk, in: Fox P.F. (Ed.), Advanced Dairy Chemistry, Vol. 1: Proteins, Elsevier, London, UK, 1992, pp. 624-656.

[24] Teppema P., Brouwer F., The pH of casein, Neth. Milk Dairy J. 30 (1976) 79-94.

[25] Udabage P., McKinnon I.R., Augustin M.A., Mineral and casein equilibria in milk: effects of added salts and calcium chelating agents, J. Dairy Res. 67 (2000) 361-370.

[26] Weaver C.M., Calcium in food fortification strategies, Int. Dairy J. 8 (1998) 443-449. 